\title{
CATHOLIC THEOLOGICAL PERSPECTIVES ON ISLAM AND CHRISTIAN-MUSLIM RELATIONS SINCE VATICAN II UNTIL TODAY
}

M I C H A E L L.F I T Z GER A L D

\begin{abstract}
This article contains the theme of catholic theological perspectives on Islam and Christian-Muslim relations since Vatican II until today. The article presents some negative opinions on Islam and some positive appreciations of Islam. Further the article looks at the Vatican II and its approach to the Islam. This is author's theological framework of thinking about Islam. Next part emphasizes the teaching of Vatican II on Islam. Finally author presents some of the consequences of respect for Islam as a religion and the developments since the Vatican Council.

Keywords

Dialogue; Islam; Nostra aetate; Christian-muslims relations; Theological perspectives on Islam
\end{abstract}

DOI: $10.14712 / 23363398.2018 .12$

667

he Church has a high regard for the Muslims." So states Nostra Aetate, the Declaration on the Relation of the Church to Non-Christian Religions promulgated by Vatican II, at the beginning of its third section. This statement must have surprised many Catholics. History illustrates that Muslims and their religion, Islam, have not always been considered with esteem or high regard. In fact Nostra Aetate recognises that "over the centuries many quarrels and dissensions have arisen between Christian and Muslims" (NA 3). This teaching of the Second Vatican Council has provided a solid basis for a remarkable development in Christian-Muslim relations throughout the world, yet there has been little change in the official teaching of the Church as regards the theological evaluation of Islam. For a better 
understanding, it will be necessary to pay attention to what has been said, and to what has been passed over in silence. Before examining in detail what Vatican II has said about Islam and Muslims, it may be useful to recapitulate briefly some previous positions.

\section{Some negative opinions on Islam}

It is not a pleasant duty to recall past opinions of Christians regarding Islam, but if there is to be some appreciation of how long the journey has been and how steep the climb to the crest of the Vatican II statements, it may be a useful exercise. Only a few illustrative examples will be given outlining different positions. ${ }^{1}$

\subsection{Islam is satanic}

A "monk of France", probably to be identified with Hugh of Cluny (1049-1119), wrote to the Muslim king of Saragossa, Muqtadir billah, a letter inviting the ruler to embrace Christianity. In it he spoke about the deceptive nature of Islam, attributing it to the work of Satan. He stated: "Satan ... deceived the children of Ishmael in regard to the Prophet whose mission they acknowledged and thereby drew many souls to the punishment of Hell."2 Though the tone of the letter was fairly friendly, this way of seeing Islam as something devilish and the Prophet of Islam as an instrument of Satan, obviously produced a strong reaction. The ruler entrusted the task of replying to a scholar, Abû l-Walîd Sulaymân b. Khalaf al-Bâjî, who repeated all the main arguments of Islam against Christianity and ended, naturally, by appealing to his correspondent to be converted to Islam. From the Christian side, Islam was seen as something diabolical since it prevented God's saving work from being accomplished. It must be admitted that this was an opinion quite common in missionary circles up to the Second Vatican Council.

I have already treated this subject in the chapter entitled "From Heresy to Religion: Vatican II and Islam", in Michael L. Fitzgerald - John Borelli. Interfaith Dialogue. A Catholic View. London: SPCK / Maryknoll, NY: Orbis 2006, pp. 109-121. For further details see Norman A. Daniel. Islam and the West: the making of an Image. Edinburgh University Press 1960, 443 p.; R. W. Southern. Western Views of Islam in the Middle Ages. Cambridge, MA: Harvard University Press 1962; Jean-Marie Gaudel. Encounters and Clashes. Rome: Pontificio Istituto di Studi Arabi e Islamici 2000, Vol. I (A Survey), xii +363 p. Vol. II (Texts), 396 p.

2 Gaudel. Encounters and Clashes. Vol. II, p. 78; cf. Vol. I, pp. 106-112. 


\subsection{Islam is a false religion}

An earlier writer, George Hamartolos, this time not in the West but in the Byzantine Empire, compiled a history of mankind from its origins to the middle of the 9th century. In the single chapter he dedicated to Islam, he compared it unfavourably with Christianity, stating that it is a religion which springs from a false prophet. "These foggy-minded and stupid men", he wrote, "refuse openly to examine the truest faith, sacred and guaranteed by God, while these hardened wretches accept the forgery to which this swindler gave the appearance of true religion." 3 At least this writer did not invoke the influence of Satan, but he gave evidence of prejudice born of ignorance. As Gaudeul remarks: "George (Harmatolos) did not know Islam, understood no Arabic, repeated what his predecessors had said but with such hatred, contempt and self-righteousness, that his readers took it for granted that what he said was true and passed it on to future generations." ${ }^{4}$ This attitude is unfortunately still found in polemical booklets from both sides.

\subsection{Islam as heresy}

Turning to someone who did have direct experience of Muslims and Islam, John of Damascus (675-753), we see that in the first century after its rise Islam is treated as a breakaway from Christianity. John Damascene shows that his information about Islam is generally correct and gives evidence of knowledge of the Qur'an. Yet each element of the religion is taken separately and not evaluated within the context of the religion as a whole. In fact it could be said that Islam is not described in itself at all, but is only considered in its relationship to Christianity. It may be remarked that it is surely unjustified to consider Islam as a Christian heresy. To become a heretic one must first belong to the Church. This obviously does not apply to Muhammad.

\subsection{Muslims as unbelievers}

Thomas Aquinas set Muslims in the category of unbelievers. He was naturally inclined to reserve the term "believer" to one who shared the Christian faith. Thomas, as a Dominican friar, was requested to compose a work to help those of his order who were preaching to Jews and Muslims. This was the origin of his Summa contra gentiles. He admitted

Ibid. Vol. II, p. 19; cf. Vol. I, pp. 67-68.

Ibid. Vol. I, p. 67. 
that he knew very little about Islam, so he concentrated mainly on the way of presenting the elements of Christian faith to people who did not accept the authority of the Christian Scriptures. In the first three sections of this work, dealing with God in Himself, God as Creator, and with the moral life as the way to God, Thomas uses rational arguments for he is speaking about truths accessible to human reason. Only in the final section, when treating the specifically Christian Mysteries, are the Scriptures used, for these truths can be known solely by revelation. It should be noted that Thomas is not trying to prove these truths, but rather to demonstrate that they are not contradictory to reason. What is to be observed here is that Thomas is not treating Islam as a corrupt version of Christianity but, implicitly at least, as a separate religion. In fact his writings could be considered the foundation for the position which classifies Islam as a natural religion.

\subsection{Islam as a natural religion}

In contrast to Christianity with its mysteries and dogmas, Voltaire exalted Islam as a natural religion accessible to all. He considered Muhammad to have been a great philosopher. Similarly Thomas Carlyle presented Islam as the work of a genius. This is surely reductionist. Yet some Catholic theologians are also inclined to treat Islam as a natural religion. What they probably mean is that this religion remains, in its approach to God, at the level of what can be known by reason alone. George Anawati, the well-known and influential Egyptian Dominican, has qualified this assertion. For him Islam can be said to be a natural religion in so far as the truths it professes are accessible to reason, and yet, for Muslims at least, it is a revealed religion since they adhere to these truths as being received from God. This would seem to correspond exactly to the Islamic view. Muslims do indeed say that Islam is a natural religion, the religion of fitra, that is the religion given by God to man at his very creation. The prophets have been sent simply to remind men of this religion. This prophetic mission culminates in Muhammad establishing Islam as the definitive universal religion. 


\section{Some positive appreciations of Islam}

\subsection{Muhammad in the line of the prophets}

The position adopted by the Catholicos Timothy I (728-823) is well known. ${ }^{5}$ Asked explicitly by the Caliph Al-Mahdi to give his opinion about Muhammad, Timothy's reply was "Muhammad is worthy of praise by all reasonable people, $\mathrm{O}$ my Sovereign. He walked in the path of the prophets, and trod in the tracks of the lovers of God". ${ }^{6}$ Timothy's reasons for this affirmation are that Muhammad taught his followers the doctrine of the unity of God, detaching them from idolatry and polytheism; he drove people away from bad works and brought them to good works; he also taught about God, His Word and His Spirit.

\subsection{An Abrahamic religion}

Coming to more recent times mention must be made of Louis Massignon (1883-1962). This distinguished Islamicist, having recovered his own Christian faith through contact with Islam, devoted his life to presenting the true faith of Islam to the West. He was no theologian and never systematised his thought but presented it in flashes of an intuitive nature. Here is how R. Caspar summarises his position: "Islam, according to Massignon, is the heir of Hagar and Ishmael, the 'excluded', driven into the desert but enjoying a special blessing (Gen 16:11-20;21:17-20;25:12-18). Muhammad receives this blessing of Ishmael 'at the providential and symbolic hour': exiled from his homeland, Mecca, like Abraham from Ur and Ishmael driven into the desert, he claims the inheritance of Abraham against Israel (the Jewish people) unfaithful to their Covenant and against the Christians unfaithful to Jesus." Islam's role is thus, as it were, to goad Jews and Christians to return to the correct understanding of their own religions. It could

5 Cf. Robert Caspar. Les Versions arabes du Dialogue entre le catholicos Timothée I et le Caliphe Al-Mahdî. Islamochristiana 3 (1977), pp. 107-175; Gaudel. Encounters and Clashes. Vol. I, pp. 34-37, Vol. II, pp. 234-245.

6 Gaudel. Encounters and Clashes. Vol. II, p. 242.

7 Robert Caspar. A Historical Introduction to Islamic Theology. Rome: Pontificio Istituto di Studi Arabi e d'Islamistica 1998 (French original 1987), p. 97. See the bibliography on Massignon indicated in this work. To this could be added Mary Louis Gude. Louis Massignon. The Crucible of Compassion. Notre Dame, IN: University of Notre Dame Press 1996; Neal Robinson. Massignon, Vatican II and Islam as an Abrahamic Religion. Islam and Christian-Muslim Relations 2/2 (1991), pp. 182-205. 
be considered almost as an "Abrahamic schism, prior to the Ten Commandments, the foundation of Judaism and to Pentecost, the foundation of Christianity". ${ }^{8}$ Massignon, who died shortly before the opening of the Second Vatican Council, certainly helped to bring about a new vision of Islam in Catholic circles though his own position, as will soon be shown, was not adopted by the conciliar texts.

\section{Vatican II and Islam. The theological framework}

It is hardly necessary to present the genesis of the texts of Vatican II concerning Islam: the single sentence in the Dogmatic Constitution on the Church, Lumen Gentium, and the full paragraph in the Declaration on the Relation of the Church to Non-Christian Religions, Nostra Aetate.$^{9}$ It is good to remember, nevertheless, that the Council's concern with Islam arose incidentally, out of the desire to produce a declaration concerning the Jews. There was no intention of providing a full discussion of Islamic beliefs and practices, nor, for that matter, of those of any other religion.

It does seem useful, however, to outline the theological framework which provides the setting for these texts. ${ }^{10}$ Two fundamental theological principles are said to be underlying the Church's approach to other religions: the universality of God's salvific will, the sacramental nature of the Church. One could add a third principle, lying between these two and connecting them, namely the necessary mediation of Jesus Christ. The framework as outlined has five parts to it.

\subsection{Grace widely given}

To say that God wills to save implies that He is ready to give His grace to bring about that friendship with Him and that sharing of His life which constitutes salvation. To say that God's saving will is universal means that His grace must be offered to all. The Council in fact speaks about the possibility of salvation for those who seek God with

8 Caspar. A Historical Introduction to Islamic Theology, p. 98.

9 Cf. Georges M.-M. Cottier. L'historique de la Déclaration. In: A.-M. Henry et al. Vatican II Les relations de l'Eglise avec les religions non chrétiennes. Paris: Cerf 1966, pp. 37-78; Robert Caspar. La religion musulmane. In: A.-M. Henry et al. Loc. cit., pp. 201-212; Robert Caspar. Islam According to Vatican II. In: Michael L. Fitzgeralg - R. Caspar. Signs of Dialogue. Zamboanga City: Silsilah Publications 1992, pp. 233-245.

10 I follow here the indications given by Joseph Farrugia. The Church and the Muslims. Gozo: Media Centre 1988. 
a sincere heart and, moved by grace, strive to do His will, following the dictates of their conscience (Lumen Gentium 16). Following one's conscience would allow for adherence to the principles and practices of a particular religion, such as Islam. The text goes on to speak about those who, without any fault of their own, do not have any explicit knowledge of God, and yet strive to lead a good life. This they do "not without grace" (ibid.). One cannot be saved without faith, at least an implicit faith, but such faith cannot exist without grace. So it is that the Constitution on the Church in the Modern World, Gaudium et Spes (no. 22), states that since Christ died for all, it is necessary to hold that the Holy Spirit, in a way known to God, offers to all the possibility of entering into the saving mystery of Christ's death and resurrection.

\subsection{Values of truth and holiness}

The Council teaches that there are values of truth and goodness which are to be recognized not only in the hearts of individuals, but also in certain collective realities. These can be considered "elements of grace", helping on the way to salvation. So Lumen Gentium 17 mentions the good that is sown in minds and hearts, but also in the rites and customs of people. This is equivalent to a mention of religions. Those who are training for the ministry are urged to learn about religions in order to recognize how much goodness and truth they possess (cf. Optatam totius 18). The missionary declaration Ad Gentes (no. 18) mentions explicitly traditions of asceticism and contemplation which are to be found in different religions. These are considered to be "seeds of the Word", and so are connected to Christ. What can be deduced from this is that religions are human expressions of the longing for God taking on a social dimension. Though the grace of God is present, nowhere are they said to be divinely appointed ways of salvation. Rather are they seen as a preparation needing fulfilment.

\subsection{Redemption and elevation}

In approaching all human realities, including religions, there needs to be an awareness of the reality of evil and sin. This means that the values of truth and holiness just mentioned exist within an ambiguous context. The Council teaches therefore that the good to be found in individuals or in their rites and customs is to be not only preserved, but also purified, raised up and perfected (Lumen Gentium 17). This is to be done through a process of enlightenment and correction (Ad Gentes 3), 
connecting them with Christ as their true source (Ad Gentes 9). The task of the Church, in conformity with its nature as sacrament of salvation, is to help to eliminate the evil that can infect human beings, cultures and religions, and also to strengthen values.

\subsection{Relation to the People of God}

The Council insists further that God wills to save human beings "not merely as individuals without any mutual bonds, but by making them into a single people, a people which acknowledges Him in truth and serves Him in holiness" (Lumen Gentium 9). This refers of course to the Church as the People of God, and yet it could be suggested that the religions are the first embodiment of this social dimension of God's saving will. The people who belong to these religions are related in some way to the People of God (Lumen Gentium 16), primarily as individuals, secondarily as belonging to the different religions. It is in fact in this context that we find the first mention of Muslims. The exact nature of the relationship is not absolutely clear. It has to be admitted that grace can be found outside the visible boundaries of the Church, yet all grace is in some way ecclesial. Perhaps the people of different religions are related to the Church because the Church, at least potentially, is related to them, in a somewhat similar way, though in a lesser degree, to how Christ, the head of the Church, is related to every human being by virtue of being the Word of God made man.

\subsection{The call to fullness}

Underlying the Conciliar teaching is an anthropology according to which the human person is intrinsically religious. Created in God's image, called to share God's life, the concrete human being never exists in a purely "natural" state. It is part of the dignity of the human person, created in the image of God, to be free. God calls for a free response. This implies a responsibility, the duty of seeking the truth. It implies too that blame will be incurred if the human person tries to shut God out, avoiding all questions about religion. This teaching on the inherent dignity of the human person, the duty to search for the truth, and the respect due to the conscience of each and every person has been enshrined in the Council's Declaration on Religious Liberty, Dignitatis Humanae. This too must be borne in mind when considering the texts on religions in general and on Islam in particular. Dignitatis Humanae upholds the free exercise of religion in society, and yet at the same time 
asserts the necessity of proclaiming Jesus Christ as the one Saviour. This holding together of two elements which might at first seem to be incompatible is found also in the declaration Nostra Aetate: human beings look to the religions for the answers to those fundamental questions that illustrate the angst of human existence, and these religions are respected for whatever is true and holy in them, yet the Church also proclaims Jesus Christ as the one in whom human beings will find the fullness of their religious life (Nostra Aetate 1-2).

\section{The teaching of Vatican II on Islam}

It has often been said that the Second Vatican Council spoke about Muslims but not about Islam. This is true insofar as the Council did not intend to give a full description of Islam, entering into a detailed discussion of what could be conceived as positive and negative aspects of this religion. The statement in Lumen Gentium (no. 16) is very succinct and thus can be quoted in its entirety: "But the plan of salvation also includes those who acknowledge the Creator, in the first place among whom are the Muslims: these profess to hold the faith of Abraham, and together with us they adore the one, merciful God, mankind's judge on the last day." In some ways paragraph 3 of Nostra Aetate could be considered an extended commentary on these lines, going on to draw out some practical consequences for relations between Christians and Muslims.

It should be noted, nevertheless, that Nostra Aetate does speak about religions, and these general affirmations should be held to refer also to Islam. The religions, as has been said, provide answers for the fundamental questions of human existence (cf. Nostra Aetate 1). Nothing that is true and holy in religions is rejected by the Church. Consequently the Church gives encouragement to its members to enter into a dialogue of exchange and collaboration with the members of other religions (cf. Nostra Aetate 2). On this basis then an examination can be made as to what the Council says, at least by way of implication, about Islam as a religion.

\subsection{Islam as a monotheistic religion}

It is not surprising that recognition should be given to Muslims' belief in the one God, and thus to the monotheistic nature of Islam. After all, this belief is a fundamental characteristic of Islam, forming 
the first part of the profession of faith and constituting the main burden of Islamic theology as one of the names given to this science, tawhid (establishing or defending the oneness of God), bears witness. What is noteworthy is the additional note in the text of Lumen Gentium 16 according to which Muslims together with us adore the one, merciful God. Such a statement could be attacked by both Christians and Muslims.

Some Christians do not wish to admit that Christians and Muslims adore the same God. Our God, they say, is essentially different since we believe in a Trinity of Persons which Muslims reject. The Council, although its documents are replete with Trinitarian references, does not go into this question here. It is content, in both its texts on Islam, to refer to some of the Beautiful Names of God according to the Islamic tradition, thereby showing that the way Muslims understand God is not one-dimensional. The affirmation together with us remains: though Christians and Muslims understand God differently, we do not worship different divinities, since God is one. Both our religions are monotheistic.

Now some Muslims too may object to the statement of Lumen Gentium. There are Muslims who attack the Christian claim to monotheism. There is a Qur'anic basis for this attack, since the Qur'an contains a reference to a Trinity consisting of God, Jesus and Mary (cf. Q 5:116). Christians may well reply that the Qur'an is denying a false Trinity; they will still be considered by some Muslims to be mushrikûn (associators), kâfirûn (unbelievers). This may be the reason why certain Muslims prefer to speak always about Allâh, not translating this term into other languages, and thus attempting to mark an essential difference - yet forgetting that Arabic-speaking Christians have no difficulty in giving a Trinitarian connotation to the same term. The text of Lumen Gentium could be taken as a discreet appeal to Muslims to respect the unity of belief in the one God, despite the difference of understanding, though this was probably not the intention of the authors of the text.

Whatever the case may be, one often sees references to "the three monotheistic religions", indicating Judaism, Christianity and Islam. That these are monotheistic religions is true, and the texts of Vatican II can be seen to bear witness to this fact. Yet to talk about the three monotheistic religions would seem to be an exaggeration. There are in fact other monotheistic religions, one could mention Sikhism or African 
Traditional Religions. ${ }^{11}$ If the three religions of Judaism, Christianity and Islam are to be brought together in a special way, another category has to be found.

A further reflection would appear to be appropriate. The conciliar texts on Islam speak about belief in God as Creator and Judge. This is also something that Christians and Muslims have in common. It is not to be overlooked since it has practical consequences, providing an opening for dialogue on the common origin and common destiny of humankind. It can also lead to a joint evaluation of the role of human beings as vice-regents (khulafâ') or stewards of God's creation, with implications for a more equitable distribution and respectful use of the earth's resources. Such a reflection is not going beyond the conciliar basis, since Nostra Aetate exhorts Christians and Muslims to work together to "preserve and promote peace, liberty, social justice and moral values" (Nostra Aetate 3).

\subsection{Islam as a revealed religion?}

Besides talking about the three monotheistic religions, Muslims often use the term "celestial" as applied to these same religions. They have a celestial origin because they claim to be based on revelation. Do the texts of the Council encourage Catholics to accept this terminology?

In Nostra Aetate, after the reference to Muslims' belief in God who is one and the Creator, there is added "who has also spoken to men". As Robert Caspar has pointed out: "This divine name, the God who reveals, is of capital importance for the religious and supernatural value of the Islamic faith. The Muslim does not merely believe in a God of reason, a 'God of philosophers' as Pascal put it, but in a living God, 'the God of Abraham, Isaac and Jacob', a God who has spoken to men, within their history, by men, the prophets, even if Christians and Muslims have a different idea of the identity and role of these prophets." ${ }^{12}$

The original amendment which led to the inclusion of the words under commentary read homines per prophetas allocutum: "who has spoken to men through the prophets". The theological commission decided to omit the reference to the prophets since it was felt to be ambiguous. The Church might be giving the impression of accepting

\footnotetext{
11 In the Post-Synodal Exhortation Ecclesia in Africa John Paul II addressed not only Catholics and other Christians, but also "those who profess the great monotheistic religions, in particular the followers of African traditional religions" (EAf 7).

12 Caspar. Islam according to Vatican II, p. 240.
} 
the prophetic role of Muhammad. The Church's constant teaching is that after Jesus Christ there is no further need of revelation. "The Christian dispensation, therefore, as the new and definitive covenant, will never pass away, and we now await no further new public revelation before the glorious manifestation of our Lord Jesus Christ" (Dei Verbum 4). Accordingly Islam is not considered by the Church to be a revealed religion. It is equally obvious that Christians do not recognize Muhammad as prophet in the way Muslims do, that is as the final prophet bringing the definitive revelation, otherwise they would become Muslims. On the other hand Muslims have difficulty in accepting any type of qualified prophetic role that Christians would be ready to attribute to Muhammad. Therefore silence was preferred on this point, to the disappointment, it must be admitted, of many Muslims..$^{13}$

Has there been any change on this point? It may be worth referring to the initiative taken by Fr. Jacques Lanfry during the Christian-Muslim dialogue in Tripoli, Libya, in February 1976. Asked to speak about the topic of dissipating prejudices and misunderstandings, he added to his text a paragraph in which he asked pardon of Muslims for the lack of respect shown, down the ages, for the Prophet Muhammad. This gesture was received with great joy by the Muslims in the assembly, and the cry of Allâhu Akbar could be heard resounding in the theatre. Moreover when Lanfry had reached the end of his paper, Sheikh Subhi Saleh of the Lebanon and another member of the Muslim delegation went over to embrace him. ${ }^{14}$ The sensitivity of Muslims with regard to their prophet has been illustrated more recently by the affair of the caricatures, as also by the reactions to the speech of Benedict XVI in Regensburg in September 2006. It could be said, nevertheless, that the initiative of Lanfry thirty years earlier was giving expression to a change of attitude rather than marking any advance in doctrine.

With regard to doctrine it is worth taking note of a statement made by John Paul II during a General Audience on 9 September 1998. He had been giving a series of talks in preparation for the Great Jubilee of the Year 2000 and within them tackled the question of relations with people of other religions. He offered this reflection: "It must first be kept in mind that every quest of the human spirit for truth and

13 See for instance Ataullah Siddiqui. Christian-Muslim Dialogue in the Twentieth Century. London: Macmillan 1997, p. 35.

14 Cf. Maurice Borrmans. Le séminaire du dialogue islamo-chrétien de Tripoli (Libye) (1-6 février 1976). Islamochristiana 2 (1976), pp. 135-170, especially pp. 151-154. 
goodness, and in the last analysis for God, is inspired by the Holy Spirit. The various religions arose precisely from this primordial openness to God. At their origins we often find founders who, with the help of God's Spirit, achieved a deeper religious experience. Handed on to others, this experience took form in the doctrines, rites and precepts of the various religions" $\left(952^{*}\right)$. No founder is mentioned by name, but if, as seems likely, Muhammad would be included by the pope in the category, this would probably constitute the most positive statement about him so far in the official teaching of the Catholic Church.

\subsection{Islam as a scriptural religion?}

The words used in Nostra Aetate, "who has also spoken to men", are significant since they underline the importance of faith for Muslims. It is a faith which flows into life for, as the declaration says, "(Muslims) strive to submit themselves without reserve to the hidden decrees of God". This is the basic attitude of islâm, which is by no means a fatalistic submission to a despotic divinity but the response of an adoring servant ('abd) to a transcendent God who remains wrapped in mystery.

Paragraph 3 of Nostra Aetate thus mentions the fact of Muslims' belief in, and response to, a God who reveals, but it says nothing about the manner of this revelation. Just as Muhammad is not mentioned, neither is there any reference to the Qur'an. Yet Islam would claim to be "a religion of the Book", and the Qur'an plays a central role in Islamic worship and life. Moreover Islam readily classifies Jews and Christians together with Muslims as "People of the Book". Christians may well object to this classification since they consider themselves to be followers of a person, Jesus Christ, and not of a book. The notions of revelation and the role of the Scriptures are not the same in the two religions.

It should be noted furthermore that there is not the same relationship between Islam and Christianity as there is between Christianity and Judaism. Paragraph 4 of Nostra Aetate states: "The Church of Christ acknowledges that in God's plan of salvation the beginning of her faith and election is to be found in the patriarchs, Moses and the prophets ... On this account the Church cannot forget that she received the revelation of the Old Testament by way of that people with whom God, in his inexpressible mercy, established the ancient covenant." Between Jews and Christians there exists therefore, as the same document expresses it, "a common spiritual heritage". 
The link between the Qur'an and the Christian scriptures, including the Old Testament, is much more tenuous. There are some references in the Qur'an to biblical elements, but the texts of the previous Scriptures are not retained as such - in fact the criticism is levelled that they have been falsified. ${ }^{15}$

So Islam, although giving an important place to the Qur'an as scripture, is not recognized by Christians as a biblical religion. That there should be a difference of appreciation on this point is not surprising. Just as Christians cannot expect Jews to accept the New Testament as the authentic interpretation and fulfilment of their scriptures, so Muslims should not expect Christians to accept the Qur'an as the authentic interpretation and definitive version of previous scriptures. A further indication of the asymmetrical relationship of the Holy books could be drawn from liturgy. Christians, in their worship, make use of the First Testament, indicating that they accept these as true elements of the revelation they have received. Muslims would never use the Hebrew or Christian scriptures during salât, their ritual prayer, thus showing that they do not accept them fully as revelation. Lex orandi, lex credendi.

\subsection{Islam as an Abrahamic religion}

Both texts of Vatican II link Islamic faith with Abraham. Lumen Gentium says that Muslims "profess to hold the faith of Abraham". Nostra Aetate states that Muslims submit to God "just as Abraham submitted himself to God's plan, to whose faith Muslims eagerly link their own".

It must be admitted that these references en passant to Abraham remain somewhat vague. Abraham's faith is recognized, but it is not said how he exemplified this faith. Muslims see Abraham as a champion of monotheism and attribute to him the rebuilding of the Ka'ba, the shrine in Mecca that has become the direction of Muslims' prayer. Christians insist on Abraham's response to God's call to leave his country for a promised land. By both religions Abraham is given as a model of submission to God's mysterious decrees. This spirit of submission was illustrated in a pre-eminent way in his readiness to sacrifice his son, an episode in Abraham's life exalted by Jews, Christians and Muslims, but with a different identification of the victim.

15 On this whole question see GRIC (Muslim-Christian Research Group). The Challenge of the Scriptures: the Bible and the Qur'an. Maryknoll, NY: Orbis books 1989 (original French edition 1987). 
There is silence above all on the question of descent from Abraham. The first version of the text to be introduced into Lumen Gentium, following the line advocated by Massignon and his disciples, read: "The sons of Ishmael, who recognize Abraham as their father and believe in the God of Abraham, are not unconnected with the Revelation made to the patriarchs." This text could have been referred to above in the sections on Islam as a revealed religion or a scriptural religion. Here attention is to be called to the elimination of the reference to Ishmael. Quite apart from the historical question of the descent of the Arabs from Abraham through Ishmael, a question which remains disputed, the silence on this point is quite consistent with the Christian position with regard to Abraham. Physical descent is unimportant; it is faith that counts. Paul, while referring to Abraham as "the ancestor from whom we are all descended" (Rom 4:1), declares that "what fulfils the promise depends on faith, so that it may be a free gift and be available to all of Abraham's descendants, not only those who belong to the Law (i.e., the Jews), but also those who belong to the faith of Abraham who is the father of us all" (Rom 4:16). Elsewhere Paul will argue that the promise made to Abraham and to his posterity is actually fulfilled in Christ (cf. Gal 3:16).

Although there are profound differences in the way Jews, Christians and Muslims see Abraham, there is nevertheless a common recognition of Abraham as a model of faith and submission. As long as there is a readiness to respect the different interpretations, the figure of Abraham provides common ground for the followers of Judaism, Christianity and Islam, which can be called with some justification "Abrahamic religions", though this term does not describe them adequately or completely. ${ }^{16}$

\section{Consequences of respect for Islam as a religion}

Islam is treated by Vatican II as a religion worthy of respect. This has certain practical consequences, some of which appear in the conciliar texts. There is an explicit recognition of the religious spirit of Muslims.

16 On Abraham see P.I.S.A.I. Forum - January 26th 1996: Abraham-Ibrahîm in the Monotheistic Traditions. In: ENCOUNTER: Documents for Christian-Muslim Understanding, 1996, no. 222-223; Bradford E. Hinze - Irfan A. Omar (eds.). Heirs of Abraham. The Future of Muslim, Jewish and Christian Relations. Maryknoll, NY: Orbis 2005. 
There is mention of certain typical expressions of Islamic religiosity, prayer, alms-deeds and fasting. These are the three central "pillars" of Islam. The first and fifth pillars, the profession of faith and pilgrimage to Mecca, are passed over, presumably because they are too strongly bound up with what is specifically Islamic.

As has been mentioned already, the Council issued a special declaration, Dignitatis Humanae, on religious liberty. Nostra Aetate, which exhorts Christians and Muslims to work together to preserve and promote liberty, should be read in conjunction with this document. Its principles apply also to Islam. So freedom of worship is upheld, not only for individuals but also in its corporate expression. This implies the possibility for a community to have its own places of worship. There is also the right to teach about one's religion, for example in schools, but also through publications and through the media in general. In all this the proviso holds that public order is to be respected. This means that the civil authorities have the right to exercise a certain control but not to deny the public practise of religion.

The recognition of Islam as a separate religion leads to an encouragement to dialogue and cooperation between Christians and Muslims. This is in fact the whole purpose of the declaration Nostra Aetate. When the amended document was presented to the Council it was explained that it was "not an exhaustive presentation of the religions and their faults and weaknesses but rather (it was) to point out the connection between peoples and religions which (could) serve as a basis for dialogue and collaboration". ${ }^{17}$

The definitive text contains a reference to "quarrels and dissensions" and there is an appeal to "forget the past" and make an effort to achieve mutual understanding. It should be appreciated that to forget does not mean to ignore, but rather not to let oneself be bound by the past. The late Pope John Paul II called for a "purification of memories", a re-examination of the past which would include an acknowledgement of wrongdoing and repentance before God. When faced with questions from the past such as the Crusades and the Islamic conquests, colonialism, the slave trade in which both Christians and Muslims were unfortunately involved, there could be room for a common endeavour to ensure that the burden of history does not poison present relations between Christians and Muslims.

17 Farrugia. The Church and the Muslims, p. 74. 


\section{Developments since the Vatican Council}

On the reflective level there has been very little change in the position of the Church with regard to Islam. One witness to this is the Catechism of the Catholic Church promulgated by Pope John Paul II in 1992. This official compendium of the teaching of the Church merely repeats Lumen Gentium 16, giving a reference in note to Nostra Aetate $3 .{ }^{18}$ The same repetition is found in what has been said by the Popes since Vatican II. Yet there are perhaps a few notes that have been sounded which, if not completely new, strike a slightly different tone. To illustrate this I wish to give a few quotations from the speeches and writings of Paul VI and John Paul II. ${ }^{19}$

\subsection{Paul VI}

In a letter to the Catholic Hierarchy and to all the Peoples of Africa (29 October 1967), Paul VI expressed "esteem for all the followers of Islam living in Africa, who possess elements in common with Christianity". The hope was expressed that these would provide a basis for "a beneficial dialogue" (241).

On 1 August 1969, during his visit to Uganda, Paul VI met with representatives of the Islamic communities. He gave thanks for the possibility of greeting "in your persons, the great Muslim communities spread throughout Africa". It was an opportunity to show his "high respect for the faith you profess" and to express the hope "that what we hold in common may serve to unite Christians and Muslims ever more closely in true brotherhood". He went on to say that he felt sure "that as representatives of all Islam, you join in our prayer to the Almighty, that he may grant all African believers the desire for pardon and reconciliation so often commended in the Gospels and in the Qur'an". The pope evoked his visit to the shrine of the Uganda martyrs and stated that, while commemorating the Catholic and Anglican martyrs, he gladly recalled also "those confessors of the Muslim faith who were the first

18 For a more detailed study see Michael L. Fitzgerald. Other Religions in the Catechism of the Catholic Church. Islamochristiana 19 (1993), pp. 29-41; also Mohammed Arkoun. Réflexions d'un Musulman sur le "Nouveau Catéchisme", ibid., pp. 43-54.

19 These are to be found in Francesco Gioia (ed.). Interreligious Dialogue. The Official Teaching of the Catholic Church from the Second Vatican Council to John Paul II (1963-2005). Boston: Pauline Books \& Media 2006. The numbers in brackets refer to the paragraph numbers. The emphases have been added, unless it is stated explicitly that they are to be found in the original text. 
to suffer death, in the year 1848, for refusing to transgress the precepts of their religion" (263).

The use of the term faith has been underlined, since sometimes it is questioned whether the term can be applied to other religions in general, and to Islam in particular. Pope Paul VI appeared not to have any hesitation on this point. The concept of brotherhood, mentioned in passing, will be further developed by Pope John Paul II.

\subsection{John Paul II}

Speaking to the Muslim leaders of Kenya, in Nairobi on 7 May 1980, John Paul II referred to "the religious patrimony of Islam and its spiritual value". He expressed the wish that the Christian heritage should be fully known, "especially to those who are spiritually attached to Abraham, and who profess monotheism". He went on to pledge: "On my part, I wish to do everything possible to help develop the spiritual bonds between Christians and Muslims" (350).

The pope seems to have been echoing here the strong words he had addressed to the small Catholic community in Ankara on his visit there in November the previous year. After quoting the passage of Nostra Aetate on Islam, he continued: "When I think of this spiritual heritage and the value it has for man and for society, its capacity of offering, particularly in the young, guidance for life, filling the gap left by materialism, and giving a reliable foundation for social and juridical organization, I wonder if it is not urgent, precisely today when Christians and Muslims have entered a new period of history, to recognize and develop the spiritual bonds that unite us, in order to preserve and promote together, for the benefit of all men, 'peace, liberty, social justice, and moral values', as the Council calls upon us to do (NA 3)” (339).

Similarly, in his discourse to young Muslims in Casablanca, in August 1985, John Paul II stated: "The Catholic Church regards with respect and recognizes the quality of your religious progress, the richness of your spiritual traditions. We Christians, also, are proud of our own religious tradition. I believe that we, Christians and Muslims, must recognize with joy the religious values that we have in common, and give thanks to God for them" (474, emphasis in the original text). There is nothing grudging here, but rather a call to spiritual emulation.

With regard to brotherhood, John Paul II, meeting Muslims in Paris in June 1980, greeted them as "our brothers in faith in the one God" (360). He made this even clearer in the Philippines the following year: 
"I deliberately address you as brothers: that is certainly what we are, because we are members of the same human family... but we are especially brothers in God, who created us and whom we are trying to reach, in our own ways, through faith, prayer and worship, through the keeping of his law and through submission to his designs" (363, emphasis in the original text). The same teaching was repeated in the message intended for the Muslim leaders of Nigeria, but in fact addressed to the Governor of Kaduna on 14 February 1982: "We both believe in one God who is the Creator of man. We acclaim God's sovereignty and we defend man's dignity as God's servant. We adore God and profess total submission to him. Thus, in a true sense, we can call one another brothers and sisters in faith in the one God" (390). Concluding, the Pope stated his conviction that "if we join hands in the name of God, we can accomplish much good" (393, emphasis in the original text). Again, when meeting representatives of the Muslims of Cameroon in Yaoundé on 12 August 1985, John Paul II said: "I call you brothers because God, our Creator, made us members of the same human family" (451).

It may be thought that this point is being laboured, but traditionally the term "brother" was reserved for fellow Christians. The World Council of Churches, in its documents, prefers to speak about "neighbours of other faiths". The use of the term "brother" by the popes can be seen as a sign of openness and friendship.

It is interesting to note that Pope John Paul II's discourses often reflect an awareness of the Islamic tradition. In the speech to the Muslims of Cameroon just referred to, there are two quotations from the Qur'an, one implicit, the other explicit. The Pope states: "The Muslims believe that God created man as his delegate, and he desires us to act as honest and trustworthy superintendents of creation" (451). The reference here is to Q 2:30 where God announces to the angels, to their horror, that he is going to place man as his deputy (khalifa) on earth. At the end of his discourse the pope describes the error of a world without God. "When man forgets that we are always the beloved creatures of God, when he tries to construct a future without God, he can only get lost. God is the origin and end of our lives, he who is 'closer to us than our jugular vein'; he is for us the guide and Master of what is just" (452). The quotation is from Q 50:16. These echoes of the Muslims' holy book are practically guaranteed to attract their benevolent attention. 
Much later, in a speech to the Islamic leaders to Senegal, given in Dakar on 22 February 1992, John Paul II referred to the "tradition of Abraham". He said: "In our respective traditions Abraham is called 'the intimate friend of God' (in Arabic, al-khalîl). He received this title because of his flawless faith in God" (743). The pope continues a little further on: "Our God is a God of peace who desires peace among those who live according to his commandments. Our God is the holy God who desires that those who call on him live in ways that are holy and upright. He is a God of dialogue who has been engaged, from the very beginning of history, in a dialogue of salvation with the humanity which he created" (744, emphases in the original). "Peace" and the "Holy One" are, of course, both among the Names of God given in the Qur'an. In a later meeting with Nigerian Muslims, in Abuja on 22 March 1998, during his visit to their country in order to beatify Cyprian Michael Iwene Tansi, John Paul II started his discourse by saying: "In turn I salute you with a greeting of Peace, the peace which has its true source in God, among whose 'Beautiful Names' according to your tradition is al-Salâm, Peace" $\left(940^{*}\right)$. In these examples we have a reaching out to the other by using terms familiar to that other.

One can notice another implicit reference to the Qur'an in the discourse of John Paul II, given in Carthage, Tunisia, on 14 April 1996, to the representatives of the political, cultural and religious components of society. The pope is speaking about the necessary conditions for a fruitful dialogue. He says: "It is indispensable first of all that it (this dialogue) be motivated by a true desire to know the other. It is not a question of mere human curiosity. Openness to others is in some way a response to God who allows our differences and who want us to know one another more deeply" (865*). These words will readily evoke for Muslims two Qur'anic texts: "If God had so willed, he would have made you one nation, but he wanted to test you concerning what he gave you. Be, then, forward in good deeds" (Q 5:48), and "O mankind, we have created you male and female and made you nations and tribes, so that you might come to know one another" (Q 49:13). It should be noticed that the pope uses the verb "allows", rather than "wills". This would seem to indicate a tendency to accept a de facto religious pluralism, rather than one which would be de jure, though this is perhaps reading too much into a short statement.

Let me end this section of selections from the speeches of John Paul II on a slightly different note. In an address to the Catholic Hierarchy of 
Egypt, received in audience at Castel Gandolfo on 20 August 2003, the pope drew attention to the importance of dialogue with Islam, both in Egypt and throughout the world. He declared: "I would like to remind you how essential it is that the world religions join forces to denounce terrorism and to work together at the service of justice, peace and brotherhood among men and women" $\left(1335^{*}\right)$. These words indicated perhaps a new phase in dialogue with Muslims, influenced by the tragic events of 11 September 2001.

\section{Conclusion}

Much more could be said about the practical development of relations between Christians and Muslims during the years since the Second Vatican Council. A complete survey would take into account the diplomatic relations established between countries with Muslim majorities and the Holy See. It would record the work done by some regional Episcopal Conferences, often with the support of the Pontifical Council for Interreligious Dialogue, both in the field of reflection and in actual encounters with Muslims. In all of this it could be seen that the texts on Islam officially proclaimed by Vatican II remain not only a constant point of reference but also a source of inspiration which has not yet exhausted all its potentialities.

Studium Theologicum Salesianum

Salesian Monastery - Ratisbonne

26 Rehov Shmuel Hanagid

P.O.B. 7336

9107202 Jerusalem - Israel

E-mail: milofitz_17@yahoo.co.uk 